\title{
Coping with COVID-19 in a non-democratic system: Policy lessons from Thailand's centralised government
}

Piyapong Boossabong and Pobsook Chamchong

\section{CpenEdition}

\section{Journals}

Electronic version

URL: https://journals.openedition.org/irpp/1382

DOI: 10.4000/irpp.1382

ISSN: 2706-6274

\section{Publisher}

International Public Policy Association

\section{Printed version}

Date of publication: 15 December 2020

Number of pages: 358-371

ISSN: 2679-3873

\section{Electronic reference}

Piyapong Boossabong and Pobsook Chamchong, "Coping with COVID-19 in a non-democratic system: Policy lessons from Thailand's centralised government", International Review of Public Policy [Online], 2:3 | 2020, Online since 15 December 2020, connection on 07 September 2021. URL: http:// journals.openedition.org/irpp/1382 ; DOI: https://doi.org/10.4000/irpp.1382

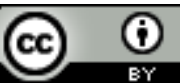

International Review of Public Policy is licensed under a Creative Commons Attribution 4.0 International. 


\section{Coping with COVID-19 in a non-democratic system: Policy lessons from Thailand's centralised government}

\section{Piyapong Boossabong}

Chiang Mai University School of Public Policy, Thailand.

\section{Pobsook Chamchong}

Chiang Mai University School of Public Policy, Thailand.

\section{Abstract}

Policy analysis in Thailand during these turbulent times (COVID-19) is based mainly on expert opinion expressed under a highly centralised and non-democratic political system. However, the government's claim of scientific rationality shows that political reasons are at play behind the scenes. Moreover, this policy domain does not interact well with the social domain as it is missing the social, contextual and experiential constructions of policy problems and solutions. Scientists are less sensitive to the social mood and fears and are thus unable to cope effectively with the psychological impact of the crisis. The static governmental mechanism also fails to work well with existing organic and flexible governance practices at a local level. This article thus suggests the importance of underscoring the need for efforts to decentralise and re-democratise political systems and suggests the practice of 'safety participation' to better articulate and integrate the essential relationships between science, politics and citizens.

\section{Keywords}

COVID-19, pandemic, policy paradox, critical policy studies, interpretive policy analysis 


\section{Introduction}

Thailand was the first country outside of China to detect a case of COVID-19. Like many other countries, the country shifted most of its focus to cope with the pandemic. The Centre for COVID-19 Situation Administration (CCSA) was formed during the first few weeks after the outbreak, through which the Prime Minister took overall leadership of the campaign to combat the virus. The centre was formed to initiate and monitor public policy within a strong hierarchical system. Its data analysis was supported by two key advisory boards known as the Medical Advisory Board, led by medical professors in well-known medical schools, and the Recovery Advisory Board, led by macro-economists. Eight operational centres were incorporated into this core centre and they were coordinated by the National Security Council. The secretary of the centre was the Deputy Secretary-General to the Prime Minister for Political Affairs (Prime Minister's Office, 2020d).

With such mechanisms of the military-supported government in place, what can be learned from Thailand? This article aims to draw lessons from a country where policy analysis in the face of the coronavirus pandemic is based mainly on expert opinions expressed in a highlycentralised and non-democratic political system. Of course, it might be that this type of system has led to successes in combating the virus as the total numbers of cases in Thailand - approximately 3,500 cases with 59 deaths from a total population of 66 million - were relatively low in comparison to other countries. Also, the military-supported government eagerly reported that the number of newly infected people was lower than 10 for more than two weeks after lateApril, before turning to zero for more than 12 weeks after 13th May (Prime Minister's Office, 2020a). However, certain phenomena are occurring 'behind the scenes', such as missing links, and hence the constraints of the Thai style of policy analysis needs to be understood.

\section{Unpacking policy discourses: Analytic perspectives}

This work is guided by a discursively oriented logic of policy analysis. This analytical lens is used to capture different constructions of meaning around policy problems and solutions, moving from the instrumental and professional discourse to the contextual and experiential discourse, the sociocultural discourse, and the political discourse (Fischer, 1995, 2003). In relation to the framework, the first part of this article analyses the instrumental and professional discourse, based primarily on numbers, graphs, maps, scientific standards, and macro-economic mindsets. The second part decodes the invisible policy intentions that give rise to political constructions of policy problems and solutions embedded in technocratic claims. This section reveals the politics of numbers through policy narratives by which some facts were included and others were ignored, based mainly on political reasons. In the third part, the analysis focuses on the missing link from official governmental interpretations of policy relevant meanings, that is, the sociocultural, contextual and experiential constructions of meaning around policy responses. The last part offers some suggestions.

With regard to methods, the review of official documents, daily announcements given by the CCSA, and news reports were the main data collection methods. The review included some secondary data from quick surveys and urgent field research as well. The everyday struggles of the people and the social mood during the pandemic were observed. Some informal interviews were also conducted with medical doctors, local politicians, shop owners, traders, street vendors and even coffee baristas. For the data analysis, the classic method of 'thick description' introduced by Geertz (1973) is applied. This method is used to unpack the different interpretations of meaning that are placed on actions and words (Geertz, 1973: 9). In doing so, different 
layers of meanings in relation to COVID-19 situations and responses are captured by employing the aforementioned framework.

\section{Scientific rationality and policy responses to COVID-19}

To cope with the outbreaks in Thailand, the number of newly infected people, their location and their backgrounds were reported and plotted on graphs and maps on a daily basis. The predictions and policy direction were based mainly on such graphs and maps. These are the standard methods of policy analysis, which can be perceived as a 'stock analysis' style. Controlling the increasing numbers of newly infected people was the key consideration for the government at that point in time. All mechanisms were activated to control society, to stop the curve on the graphs and the scattering points on the maps, guided by medical standards and procedures. In the same vein, protection from economic collapse was considered by the reliance on macro-economic analyses.

In overview, there were three main turning points that constituted the major changes in policy interventions towards the COVID-19 situation in Thailand. The first turning point was when the New Year festivities led to the travelling of numerous people back to their hometown from Bangkok, the capital city. The outbreaks rapidly spread from the first few cases found in Bangkok to every region of the country. The graphs showed that without stricter controls, the situation would almost certainly worsen. Numbers, graphs and maps were thus clearly influencing the policy decisions. During this period, all flights from the regions surrounding Wuhan, China, were cancelled. Strict regulations then followed, including a quarantine period of 14 days and strict adherence to social distancing measures. Also, the stark control extended from the mobility of people to the control of products and services. The government therefore controlled the price of essential products, especially face masks and alcohol hand gel sanitisers. From 4th February 2020, all shop owners selling face masks and hand gel sanitisers at a higher price than the one stipulated were jailed (Department of Internal Trade, 2020a). Additionally, the government did not allow the sale of alcoholic beverages, the opening of 'unnecessary' shops in malls, and the serving of food at restaurants and other food outlets (Department of Internal Trade, 2020b).

The second turning point was when the situation turned out to be even worse as a consequence of some Thai workers returning from countries where there was a high rate of infection. A medical professor who was the president of the Medical Advisory Board of the CCSA gave an analysis that pointed to an increasing trend, illustrated with up-to-date graph data, showing the existing medical capacity and facilities, which the country would not be able to handle within a very short space of time. With this, the situation might have looked out of control without any effective responses at this stage. The government thus adopted stricter and more active measures. On 2nd March 2020, the CCSA announced that people from the countries where the number of cases was high would not be allowed to enter Thailand, while Thai citizens returning from those countries were put in the state quarantine programme (Ministry of Health, 2020).

The government also shifted from the control of people and products to the control of places as further measures were employed to curb the spread of the virus. As a result, in mid-March, the government ordered the closing of movie theatres, barber shops, bars, spas, boxing stadiums, sports stadiums, fitness establishments, traditional Thai massage parlours, healthcare massage places, and entertainment venues (Department of Disease Control, 2020). Until 25th March 2020, the regulation of the government was at its strictest level after the Prime Minister announced curfew measures by referring to the declaration of the Emergency Decree on Public 
Administration in Emergency Situations 2005 (Prime Minister's Office, 2020b). With this, border checkpoints, airports and malls were closed, while governmental offices and educational institutions had restricted access.

From stricter regulations to more active measures, the government, following the advice of macro-economists from the Thailand National Bank, spent 100,000 million Baht to protect financial and stock markets (Post Today, 2020). This was in response to the fact that after the situation became worse, the stock market fell more than $10 \%$ for a total of three consecutive days and the graph tended to mirror the situation during the economic crisis of 1997. Helping the most vulnerable people in society affected by the pandemic was also given top priority. The government subsidised informal labourers who were not registered in the social security system and, later, farmers with 5,000 Baht per month for three consecutive months (Ministry of Finance, 2020).

For the last turning point (with the last update of late-August), the regulation was more relaxed after early-May because fewer than 10 new cases were found over a duration of two weeks. The CCSA thus announced that some business activities could be re-opened, but only if they redesigned their shops and restaurants to permit strict social distancing measures. Markets were opened, but customers without face masks were not allowed to enter the premises. Barber shops were also allowed to operate but they were asked to record customers' information, including their names and mobile phone numbers. Some domestic flights were allowed from that point onwards, but to cross the different provincial territories, citizens needed to report to the authorities in advance. Besides, as the number of new cases was low, the government started using an active testing system. Before 5th May, only 228,760 cases were tested at the hospitals. After this date, the government started to actively test 6,000 cases per $1,000,000$ of the population (Puttanont, 2020).

\section{Decoding political reasons and the power of policy narratives}

It was clear that most scientific and economic claims supported strict governmental control and the priority for macro-economic development, which fitted well with the main ideology of political leaders with a background of serving in the army, especially the Prime Minister himself. They were especially sensitive to security, safety and stability. In the face of post-truth politics, the political leaders exercised the power of knowledge through the experts by choosing some facts and ignoring others, based on their prior assumptions and priorities for the regime. The role models and best practices praised by the CCSA were the countries with authoritarian interventions, especially China and Singapore. On the other hand, the centre showed numbers and graphs comparing the situation in Thailand with democratic countries like Italy, the US, and the UK in order to point out that without strict controls there would be a possibility of failing to control the virus, as in the case of the named progressive democratic countries.

The politics of expertise can also be observed in the facts chosen or ignored with regard to the announcement of a curfew. Referring to the medical standards and the increasing number of newly infected people, the government announced this regulation which was stricter than the general lockdown measure. The nationwide curfew was enforced for more than two months. This regulatory policy instrument in turn hid and repressed the political struggles and tensions which had thus far been evolving, especially among the young people and at the grassroots level, as a consequence of the dissatisfaction with what were perceived as unfair politics and the illegitimacy of the military-supported government.

Although conflicting policy values, known as the policy paradox (Stone, 2002), in relation to 
security versus liberty can be balanced, with this authoritarian style the demand for freedom is blamed for causing many problems. Under these measures, the government can then pause any political movements under the cloak of 'safety reasons'. Demanding freedom at this time, thus, can be seen as a 'sin'. There was also a case that complaints addressed by citizens were simply discredited by pointing out that they were sent by the opposition party, and, as a result, would not be investigated (Yanjinda, 2020).

Thus, in the name of instrumental and professional approaches, the authoritarian style of policy interventions was rising behind the scenes and framed under the political construction of policy problems and solutions. The government also operated under a highly centralised system with the endorsement of regulations as the main policy instrument in handling the pandemic. The CCSA, led by the Prime Minister, controlled the distribution of all resources. The role of the military was extended, especially through the initiative entitled 'Army Delivery', which allowed soldiers to assimilate into most social activities thus facilitating the strict surveillance of citizens. Consequently, the applauded and effective measures in controlling the number of cases with centralised and non-democratic systems can be the key constraints towards long-term decentralisation and democratic prospects in this country.

Turning to how scientific and economic claims were used strategically to deliver political reasons, the analysis focuses on the power of policy narratives by which chosen facts were put in the storyline for the purpose of disseminating them throughout the general public. Time series analysis and process tracing were the clear case of the politics of numbers embedded in policy narratives. The official communication put political and even moral meaning into such numbers. For example, on 25th March 2020, the Prime Minister referred to the increasing numbers of new cases to develop a narrative of threats, which in turn legitimised the announcement of a state of war. His narrative was compounded with the use of military terms: medical doctors were called 'warriors', and to handle the disease was referred to as to 'fight the enemy for the survival of the nation' (Yanjinda, 2020). In doing so, the CCSA used the Emergency Decree on Public Administration in Emergency Situations 2005, which was in fact expected to be implemented during war-time situations, although to handle the situation the government could have chosen to use the basic law known as the Contagious Disease Control Act 2015.

With the Emergency Decree, the government announced the curfew that prevented the organisation of any political movement. This act helped the political leaders to stop the opposition from challenging them. The Prime Minister himself claimed with the conservative narrative that Thai citizens needed to leave political conflicts related to the past behind and stated that he looked forward to the people winning the 'battle' over the pandemic by cooperating with the government. Many people with painful political stigma who criticised the government at this period were accused of being 'selfish' by right-wing populists with their politics of ignorance. Moreover, the act restrained people frustrated about government measures from collectively raising their voices, something which might have affected the government's image, such as the poor who did not get a subsidy from the government and the people who had lost their jobs but did not receive any compensation from the Social Security Fund (Pradit, 2020).

Moreover, the CCSA spokesman not only put together numbers and medical opinions, but also included moral guidance. For example, while he made the technocratic claims about numbers of new cases separated by locations, he guided the morality of the nation by mentioning that the entertainment zones and Thai boxing stadiums had been tested and found to have many new cases, and thus, teenagers and gamblers needed to behave better and to be socially responsive individuals working for the 'good' of the country. This view assumed that young 
people and boxing lovers caused problems as they only cared about their personal enjoyment. Besides, the elite framing of morality also led to the measure banning the sale of alcoholic beverages for the whole country as alcohol drinking was presumed to lead to group activities and hence to the spread of the virus (Department of Internal Trade, 2020a).

\section{Missing links from sociocultural, contextual and experiential under- standings of policy problems and solutions}

Most policy responses were one-size-fits-all macro-interventions and non-inclusive processes. The clear measure was to provide informal labourers and farmers with the same amount of money, wherever they were located. Target groups were screened using an artificial intelligence (AI) system that extracted static data from an out-of-date and incomplete official registration system. In addition, the Prime Minister announced a nationwide curfew, limiting the economic activities of small enterprises, blue-collar workers and even some vulnerable and marginal groups. As found from the quick survey by Pradit (2020) in Chiang Mai, at least 40 vulnerable groups were affected by the curfew in this city, including sex workers, the homeless, other ethnic groups and migrants.

As a consequence of these macro-oriented one-size-fits-all and non-inclusive interventions, COVID-19 policy responses in Thailand were clearly less sensitive to sociocultural understandings of policy problems and solutions. The problem of the official identification of the informal sector' was a clear example of the insensitive policy domain. With the slogan 'leaving no one behind', the government proposed the direct provision of face masks, food, and even money to help the informal sector. However, a survey of one informal settlement by Juntawong and Patan (2020) found that no slum resident gained any benefit from those measures, as these people were not counted in the official classification.

With the 'smart' system, the government seemed to create more distance from society and its citizens. For example, the online application, the AI screening process, and the automatic money transfers created a significant amount of frustration, especially for those at the grassroots level, as people were excluded from the systems without any clear explanation. The CCSA claimed that the smart system could avoid bias and even corruption from personal subjective judgement, but those excluded did not get a chance for any specific consideration of their individual cases. Without empathy, data processing turned out to be a painful system that was unable to screen the concerns and struggles of ordinary people.

Regarding the mindset of policymakers, their attitude was less sensitive to social moods, fears, panic, and other related public emotions which were natural responses to so much risk and uncertainty suddenly emerging in their everyday lives. For example, the measure to prohibit all collective activities with no exception was less sensitive to religious groups, especially the Muslims in the south of the country, a region with a long history of tensions with the central government. Reporting a suicide rate that was lower compared to previous crises was another example of a less emotional and sensitive mindset. With this, the CCSA stated that to commit suicide was normal during crises. It was thus not counted as a real problem to be solved, even though after being exposed to the unreliable compensation system, 38 people attempted to commit suicide, 28 of whom succeeded, during 1-21 April 2020 (Sattayanurak et al., 2020).

While the number of physical deaths was reported every day and were a serious concern, social and economic deaths were less prioritised. These conflicting policy values were traded off differently between policymakers and some people in society. To consider social and economic deaths, many invisible threats were embedded in the socio-economic structures. Such threats 
included the fact that to suffer not only stemmed from the fear of infection, but also from the fear of being socially frustrated, isolated, and losing one's income. A clear example was the case of the workers returning from South Korea after the large outbreaks there being referred to as 'the little ghosts' by the CCSA spokesman and the media. The use of this metaphor led to them being viewed as 'disgusting' by the general public, people who were dying 'inside'. In addition, the strong focus of the government on physical deaths led to many constraints on economic life. With unfair structures in place, migrant workers were laid off without compensation. Also, within this unjust system, only large corporations possessing an economic monopoly, their own logistics or advantages from economies of scale could survive, while the supply chains of almost all small enterprises were adversely interrupted. The informal interviews with shop owners, traders, vendors in the local markets, and coffee baristas in Chiang Mai found that those who could still sustain their business could do so mainly because they had saving. They expected that the lockdown would soon end, as they would be able to hold up their businesses with cash-only transactions for the next few months.

Thus, social injustice and the economic inequality were perceived widely in the social domain as the major policy problems after the COVID-19 situation revealed how unfair and unjust society was. With this, the reaction of laypeople was noticeable as they pointed to the need for solutions to such structural constraints. However, the existing policy responses in their view seemed to extend the gap rather than bridge it as the consequence of the fact that the government traded off economic efficiency over equity by focusing more on helping large corporations that contribute more to the nation's GDP. Some policy interventions also left the people at the grassroots level suffering a 'double whammy'. For example, the curfew and the ban on selling alcoholic beverages affected sex workers and migrant workers who worked at bars and nightclubs. These people had no access to any compensation and social protection (Jatupitpornjan and Teeracheevanon, 2020). Rather than show concern for this unfair treatment, the government paid more attention to the creation of fake news and misinformation which served to highlight the 'success' of policy responses and boost the government's image through the Operational Centre for Mass Communication and Social Media under the CCSA (Yanjinda, 2020).

Beyond the poor connection between policy responses and the sociocultural understanding of problems and expectations of solutions, it was found that contextual and experiential sensibility was missing. For example, the CCSA spokesman kept saying that everyone needed to stay at home to help the nation. This was not sensitive to the homeless, slum residents and migrants. Similar to the aforementioned 'little ghosts' phenomenon, some people in Bangkok decided to move back to their hometown as they were part of the 412,212 workers made redundant as a result of the virus (The Standard, 2020). However, these workers were then blamed for spreading the virus. Also, their real home was not the same anymore, as a sense of otherness was created and they grew more suspicious of their neighbours upon returning home (Parks, Chatsuwan, and Pillai, 2020).

Some of the poor were blamed for spreading the infection because they did not follow the strict quarantine guidelines. The CCSA spokesman pointed this out daily, blaming such selfish behaviours without understanding these people's personal struggles. The quick study completed by Kasepiban (2020) on the social and economic impacts of the quarantine system during COVID-19 in Thailand found that in some cases people could not stop working as their expenses could only be met and covered by their daily income. Several people thought that they might be infected, but were $50 \%$ sure they could avoid being tested as the cost of the existing passive 
testing system, available only at the main hospitals, was too high for them, both in terms of payment and the cost of travelling to the nearest hospital. This was even more complicated for the migrants with symptoms who hailed from neighbouring countries as they had no rights to access health care services in Thailand; they had nowhere to go. Thus, it was too easy to blame their behaviour and even their hygiene without putting in place special measures to help them.

Additionally, the traditional mindset of Thai elites who expect an abundance of tasty and cheap food everywhere in Thailand further compounded the situation. Providing food was not the main focus of the central government at the time. The only related focus was to make sure that the food supply chains of the large food corporations could operate properly, regardless of the fact that these corporations dominated the food markets, exploited labourers, supported chemically-contaminated food, and greatly constrained the possible growth of small food vendors (Boossabong, 2019). In the particular context of Chiang Mai, we observed during lateMarch to early-April that many people stood in long lines waiting for food provided by the civil society there. It is highly likely that these people could not afford to buy food from the modern trade system controlled by the large corporations and had to rely on charitable handouts (i.e. food banks and soup kitchens).

COVID-19 related problems were thus context specific and depended highly on direct experiences. With this in mind, numerous local actions through existing organic and flexible governance practices emerged to cope with these situations. Unfortunately, most of these actions were not incorporated into the official policy interventions through the existing static governmental mechanisms. The centralised government system not only failed to recognise them, but also interrupted their actions, reasoning that these micro-operations might lead to a substantial increase in the infection rate because they broke social distancing rules.

One of the outstanding cases aimed at meeting the needs of the people was the initiative referred to as 'Community Kitchen', led by civil society organisations. This operation aimed to allocate daily food boxes to people in need (Sankham, 2020). However, this local action was constrained by central regulations. Under the Emergency Decree, some locations of the food allocation activity were banned as the government raised concerns about the potential transmission of infections among the poor people standing in line waiting for food (MGR Online, 2020). There were also cases of poor people resisting by remaining in the line after officials had asked them to leave, and then one of the officers seizing food boxes from the poor people and throwing them away (Thairath Online, 2020).

The case was different in the cases where local actions were agreed to and credit was given to the central government for organising them. The Basic Community Health Care Volunteers, for example, worked actively at the local level knocking at doors to check whether each member of the community was able to handle the situation. They also had a key role in monitoring the daily activities of community members who had to self-quarantine. An assessment undertaken in March 2020 found that these 1,040,000 local volunteers accessed 12 million people at the community level and brought 2,266 high risk spreaders to local hospitals. This intervention was recognised by the World Health Organisation (WHO) as the best-practice to cope with the pandemic from the bottom up (Real News Thailand, 2020). Although they were referred to as 'volunteers', they actually received a salary from the government and worked under the Ministry of Public Health and the Ministry of Social Development and Human Security. Thus, the CCSA referred to them as a part of government actions that enhanced the effectiveness of the screening system at the community level, which turned the sense of caring into monitoring. 
In addition, a case of sharing food inside a pantry, referred to as 'Sharing Happiness Pantry', was initiated by one temple. It was simple, with the idea that one pantry was placed in the most accessible public location. Whoever wanted to donate food could come and put it there for someone in need to walk into the pantry and take what they needed. The government agreed with this and extended the practice to at least 249 pantries in 51 provinces, along with some initiatives led by active citizens themselves (MoneyGuru, 2020). However, the CCSA was less sensitive to the struggles that the majority of people were facing, with the Prime Minister himself blaming people who 'took too much food' from the pantry and warning that the government would install security cameras to monitor them; once again, this turned the sense of sharing into monitoring and this time shaming as well.

\section{Confronting centralised government: Towards a participatory alter- native}

Although this case proved that the pandemic could be controlled effectively with a highly centralised system and non-democratic system in place, the political tensions and social mood were not responded to in a constructive way. Several people also raised questions regarding the trustworthiness of the number of cases and the transparency of data processing (Yanjinda, 2020). Thus, the relationships between science, politics, and citizens needs to be discussed. About science and politics, to refer to and use medical doctors' expert opinions was seen as a political strategy to save the image of the government. Generally speaking, the government's image was already poor before the pandemic began, reflected in mass student-led protests across the country. The swaying opinions of medical doctors was able to provide a 'rebirth' of the government's image as they were given a high level of trust in society because the best high school students in the country had gone to good medical schools. With a more positive image attained, the 'negative image' was turned on dissenting citizens who raised political, economic, social or humanitarian complaints. Ultimately, scientific evidence functioned in policy narratives not only to support reasonable actions by the government, but also to legitimise political messages and the moral guidance that was being offered to the population. Medical professionals did their best to promote safety, but this does not mean that the military-led government controlled medical doctors or other doctors did not follow their professional code. The actual point is that the government utilised medical information to discredit voices raised by the opposition.

As for the relationship between politics and citizens, Thailand's case shows that authoritarian politics were primarily used to control, monitor, blame, and generally make citizens feel ashamed in the name of scientific and economic principles. Such politics also utilised wartime terminology, and within a 'state of war' everyone needed to make a sacrifice for the nation by cooperating with the instructions given by the CCSA. By pointing this out, we do not question whether the government lost control of a very dangerous situation, as in other countries; instead, we merely question whether the measures taken were too strict. There are certainly both positive and negative impacts from 'too strict' or 'too loose' measures, but we cannot advocate for either of them. Despite harsh measures being effective at the current stage, there are questions about the effectiveness in the long run, as people cannot live their political, social, and economic lives in such an unnecessarily strict political atmosphere. Additionally, the relatively small number of COVID-19 cases derives not only from the government responses, but also from the twin Thai cultural habits of social distancing, whereby only people who are close can touch each other politely, and the culinary norm of eating hot food and using a serving spoon (Beech, 2020). 
To better articulate and integrate the essential relationships between science, politics and citizens, Thailand needs to address the need to decentralise and re-democratise political systems. In decentralisation, top-down regulatory and distributive policies should be increasingly replaced by distributive ones that give a higher priority to the weak at the grassroots level. The redistribution of resources could help the handling of specific challenges in different regions. This could allow the emergence of strong local leaders and stimulate local initiatives to cope with the problems at hand. With a highly centralised system, Thailand also lost the opportunity to take advantage of strong, natural, and informal networks among neighbouring local authorities that have the potential to make sustainable changes (Chamchong, 2020).

To re-democratise would reduce the domination of political leaders and experts as well as make possible options other than the strict regulations aimed at effective control. Concerning the role of experts, to democratise does not mean to ignore expert opinions as there is no doubt about the genuine advice provided by medical doctors; rather, it means to accept that the opinions of scientists are not the only opinions that are valid (Fischer, 2009). Moreover, it should be noted that certain voices are not the only statement of objective facts. While the Thai government raises its voice with some chosen facts and moral attachments, it should also acknowledge citizens' voices that pose different moral standards and even emotions, in line with the situation in many other countries (Weible et al., 2020).

However, the discussion on re-democratisation raises a challenge regarding the role that democratic participation plays in a risky situation. It is dangerous to ask the government to shift its focus from security to liberty, because obviously safety from infection cannot be guaranteed with unlimited freedom. This case is a clear example of the policy paradox in which the freedom from coercion by others can harm society and the fact that positive liberty requires having health care and physical security (Stone, 2002: 115). As a consequence, the suggestion rather points to the practice of what we call "safety participation", which refers to the role of the government in allowing and ensuring the participation of citizens by preventing any possible harm that such participation may cause. For example, the government can scale up the practice of Khon Kaen City, which created an online open platform to allow citizens to air their grievances to specific agencies which were ordered to respond to citizens' demands (Khon Kaen Contagious Disease Administration Committee, 2020).

Apart from hearing demands raised by citizens, more active safety participation can also include the role of government in supporting the actions of the existing social forces in specific areas. These forces are mostly area-based and operated by local actors, such as civil society organisations, temples, active families, and local schools. Their participation in helping the government to provide services (e.g. food and handmade face masks) at the grassroots level while adhering to strict social distancing rules would be safer than the operation of the government itself, which usually sends officers from elsewhere to the area. This is a problem as officers from different areas may well be infectious. With this active safety participation, the government could also address and balance the physical deaths with the economic and social deaths.

At the same time, to incorporate social forces into the policy domain, the government might move away from the old-fashioned 'carrots and stick' method and its 'sermonising'. This option is productive as organic and flexible governance practices from below really existed, as noted earlier. With a more open democratic participation guided by safety principles, the government would be able to enforce and facilitate micro-level interventions to support the existing macro-level interventions with more inclusiveness and sensitivity to sociocultural, contextual, and experiential challenges. To do this, the CCSA needs to use the Contagious Disease Control 
Act 2015 instead of the Emergency Decree on Public Administration in Emergency Situations 2005. If the government can shift the legal framework, it would be able to move from 'absolute control' to 'control with care', allowing officials 'to hear' and 'to work with' citizens. This would be the way towards a better articulation and integration of the relationships between science, politics and citizens.

As it is presented, most people can see the political reasons behind this as it is clear that the situation has actually improved with time. However, the government still announced the expansion of the declaration of the Emergency Decree from the end of May to the end of June in order to maintain control of possible political movements. In any case, after no new cases were recorded for roughly three months, the pro-democracy movement started organising rallies again in July and August, leading the government to expand the Emergency Decree once more until the end of October to curtail the right to assemble and therefore make demonstrations technically illegal (Prime Minister's Office, 2020c). The largest political movement in the history of Thailand was then organised by students during 14th to 15th October to criticise the authoritarian control of the military-led government. This movement also pointed out the unfair treatments of the COVID-19 policy responses. They argued that the strict control of COVID-19 was used for political purposes, in particular to control the opposition of the government. They further emphasized that the rules were flexible for the supporters of the government, including the royal family. For example, the King and the Queen were allowed to travel freely from Germany and Switzerland to Thailand without state quarantine. Almost all royal family members did not wear masks when they interacted with the public. In addition, 630 million (in US dollars) were spent to promote the monarchy, while the economic situation turned very bad, including high levels of unemployment (Jatupitpornjan and Teeracheevanon, 2020; Pracha Thai, 2020; The Standard, 2020).

\section{Concluding remarks}

In the case of Thailand, the lessons to be learned concern the policy interventions during the crisis through the highly centralised system and the non-democratic style that was employed by the government. Some might say that the issue of COVID-19 is largely technical and, with that, more democratic participation might not help. But that outlook is flawed because, with such a technical issue, social and political elements are embedded in it, and citizen participation can bridge the gap of the technical perspective and operation by creating additional and mutual support mechanisms, especially at the local level. Also, some might be concerned that allowing the COVID-19 deniers to participate is dangerous. We would emphasise here that what we propose is not about participation in making a policy direction, but rather in operating at the particular scales inaccessible to governmental mechanisms. While the highly centralised system and the authoritarian style did not work well at the bottom, we see the potential of many existing organic social forces that mobilised resources to support people at that level. With this, the government could benefit by allowing these forces to participate in supporting vulnerable groups. Thus, our main point is to incorporate them in the governance system by allowing some degree of participation with the practice of social distancing and the condition of wearing face masks facilitated by local government structures to protect the risks emanating from COVID-deniers.

Ultimately, this article has illustrated how critical and interpretive approaches can help us understand policy discourses by unpacking different constructed meanings among scientists, politicians, and citizens. Such discourses include instrumental and professional discourse, 
contextual and experiential discourse, sociocultural discourse, and political discourse. It also contributes to the debates around the policy paradox from the new paradox of 'physical death' versus 'economic and social death' to the classic paradoxes of 'economic efficiency' versus 'equity' and 'security' versus 'liberty'. To balance these conflicting policy values, we point out that the government needs not only to decentralise by focusing more on redistributive policies that set a higher priority on the weak in society, but also to re-democratise by focusing more on supporting the safety participation of social forces in helping each other to build up hopes and cope with fear.

\section{Bibliography}

Beech, H. (2020). No One Knows What Thailand Is Doing Right, but So Far, It's Working. The New York Times. Retrieved from :

https://www.nytimes.com/2020/07/16/world/asia/coronavirus-thailand-photos.html?referringSo urce $=$ articleShare

Boossabong, P. (2019). Governing Bangkok's city food system: Engaging multi-stakeholders for smart, sustainable and inclusive growth. Journal of City, Culture and Society, 16(1): 52-59.

Chamchong, P. (2020). How cultural and organizational conditions impact on policy entrepreneurship: evidence from Thailand. Journal of Asian Public Policy, 13(1), 79-93.

Department of Internal Trade (2020a). The Control of Products and Services. Retrieved from: https://www.dit.go.th/Content.aspx?m=12\&c=27795

DepartmentofInternalTrade(2020b).PursuanttoExportNotificationNumber8of2020. Retrievedfrom: https://www.dit.go.th/Content.aspx?m=12\&c=27843

Department of Disease Control. (2020). The Announcement of Risky Venues. Retrieved from: https://ddc.moph.go.th/viralpneumonia/file/laws/laws_02.pdf. Retrieved March 6, 2020.

Fischer, F. (1995). Evaluating Public Policy. Chicago: Nelson-Hall.

Fischer, F. (2003). Reframing public policy: Discursive politics and deliberative practices. Oxford: Oxford University Press.

Fischer, F. (2009). Democracy and Expertise: Reorienting Policy Inquiry. Oxford: Oxford University Press.

Geertz, C. (1973). The interpretation of cultures: Selected essays. New York: Basic Books.

Kasepiban, N. (2020). Social and economic impacts of the quarantines during COVID-19 situations. Chiang Mai: Khonthai 4.0 research spearhead.

Khon Kaen Contagious Disease Administration Committee. (2020). Measures for preventing, protecting and controlling COVID-19 in Khon Kaen. Retrieved from:

http://www.khonkaen.go.th/khonkaen6/fileDir/proGen/20200318-COVID-19.pdf

Jatupitpornjan, P. \& Teeracheevanon, T. (2020). Measures and mechanisms for coping with social and economic impacts of COVID-19. Bangkok: Thailand Science, Research and Innovation.

Juntawong, J. and Patan, N. (2020). The survey of the impacts of COVID-19 situations to slum residents in Mae Kha, Chiang Mai. Chiang Mai: Khonthai 4.0 research spearhead.

Ministry of Finance. (2020). Measures to help and compensate people from the impacts of 
COVID-19. Retrieved from:

https://www.mof.go.th/index.php/th/files/2019-07-31-16-27-57?page=3

Ministry of Health. (2020). The notification of the Ministry of Health on countries and territories considered as high risk for COVID-19 infection. Retrieved from

http://www.ratchakitcha.soc.go.th/DATA/PDF/2563/E/052/T_0013.PDF

MGR Online. (2020). The officials banned the free distribution of food to vulnerable groups. MGR Online. Retrieved from:

https://mgronline.com/onlinesection/detail/9630000041734

MoneyGuru. (2020). 249 Sharing Happiness Pantries All Around the Country. Retrieved from: https://www.moneyguru.co.th/lifestyle/articles

Parks, T., Chatsuwan, M., and Pillai, S. (2020). Enduring the Pandemic: Surveys of the Impact of COVID-19 on the Livelihoods of Thai People. Bangkok: Asia Foundation.

Post Today. (2020). Urgently forming the special fund with 100,000 million Baht to help the financial and stock markets. Post Today. Retrieved from:

https://www.posttoday.com/finance-stock/news/618432

PrachaThai.(2020).Thepublicbudgetforpromotingthemonarchyin2020.PrachaThai. Retrievedfrom: https://prachatai.com/journal/2020/03/86761

Pradit, A. (2020). The initial survey of the impacts of COVID-19 situations on people in Chiang Mai City. Chiang Mai: Khonthai 4.0 research spearhead.

Prime Minister's Office. (2020a). The Daily Report of the Centre for COVID-19 Situation Administration. Retrieved from:

https://media.thaigov.go.th/uploads/document/66/2020/03/pdf/Doc_20200314161812000000. pdf

Prime Minister's Office. (2020b). The Declaration of the Emergency Decree on Public Administration in Emergency Situations 2005. Prime Minister's Order. Bangkok: Prime Minister's Office.

Prime Minister's Office. (2020c). The Expansion of the Declaration of the Emergency Decree on Public Administration in Emergency Situations 2005. Prime Minister's Order. Bangkok: Prime Minister's Office.

Prime Minister's Office. (2020d). The Formation of the Centre for COVID-19 Situation Administration. Retrieved from:

https://media.thaigov.go.th/uploads/document/66/2020/03/pdf/Doc_20200314161812000000. $\mathrm{pdf}$

Puttanont, W. (2020). Active measures to test COVID-19 for 85,000 cases per month. The Bangkok Insight. Retrieved from:

https://www.thebangkokinsight.com/351602/?fbclid=IwAR2iTLCEMwgklNo-h8doPYp0t4k2diYBxIBpN9uX9EBa2Te9zaKt1Gi0z4s

Real News Thailand. (2020). Local hero flighting COVID-19. Real News Thailand. Retrieved from: http://realnewsthailand.prd.go.th/newsdetail-rnt.php?nid=2652

Sattayanurak, A., Preechasillapakul, S., Pintoptang, P. et. al. (2020). Deaths and Suicides from the Impacts of COVID-19. Bangkok: Dynamics of Urban Poor in the Changing Urban Society Research Programme, Thailand Science Research and Innovation. 
Sankham, V. (2020). Labour, COVID and community kitchen: post-COVID solutions? Real Frame. Retrieved from:

https://realframe.co/communitykitchen

Stone, D. (2002). Policy Paradox: The Art of Political Decision Making (Revised edition). New York and London: W.W. Norton and Company.

Thairath Online. (2020). The poor and homeless in Bangkok got angry as the officials banned the free distribution of food. Thairath Online. Retrieved from:

https://www.thairath.co.th/news/local/bangkok/1827816

The Standard. (2020). The unemployment rate in the face of COVID-19. The Standard. Retrieved from https://thestandard.co/registration-for-unemployed-in-april-nearly-300000-people

Weible, C.M., Nohrstedt, D., Cairney, P. et al. (2020). COVID-19 and the policy sciences: initial reactions and perspectives. Policy Sciences, 53, 225-241.

https://doi.org/10.1007/s11077-020-09381-4

Yanjinda, J. (2020). Fake news and misinformation during COVID-19 in Thailand. Chiang Mai: Khonthai 4.0 research spearhead. 